\title{
The Destruction of Indoleacetic Acid. III. Relationships between Peroxidase Action and Indoleacetic Acid Oxidation
}

\author{
PETER M. RAY \\ From the Department of Botany, University of Michigan, Ann Arbor, Michigan \\ Received July 2, 1959
}

\begin{abstract}
The indoleacetic acid (IAA)-oxidizing enzyme preparation from Omphalia flavida exhibits peroxidase activity on pyrogallol with an optimum at $\mathrm{pH} 3.5-3.7$, like that for the IAA-oxidizing activity. It shows no polyphenolase activity. Peroxidase and IAA-oxidizing activities run parallel both during thermal inactivation and in course of purification of the enzyme, and are therefore considered to be due to one enzyme.

IAA inhibits peroxidation of pyrogallol by the enzyme, $50 \%$ inhibition being obtained at about $7 \times 10^{-6} \mathrm{M}$. The inhibition appears to be specific to substrates of the oxygen-consuming activity of the enzyme. IAA destruction is inhibited at the same time, even though an excess of $\mathrm{H}_{2} \mathrm{O}_{2}$ is present. IAA is not destroyed at an appreciable rate in the absence of $\mathrm{O}_{2}$, even if substrate amounts of $\mathrm{H}_{2} \mathrm{O}_{2}$ are present, whereas pyrogallol peroxidation is not influenced by the absence of $\mathrm{O}_{2}$. IAA oxidation is lightreversibly inhibited by $\mathrm{CO}$; the inhibition is affected by $\mathrm{O}_{2}$ concentration. A possible interpretation of the results is that the reaction depends upon a free-radical mechanism involving the formation of ferrous peroxidase.
\end{abstract}

\section{INTRODUCTION}

The involvement of peroxidase in oxidation of indoleacetic acid (IAA) by extracts of plants was suggested by Goldacre (5). IAA-oxidizing activity has since been found generally to be associated with the presence of peroxidase. The principal exception appears to be the IAA-oxidizing activity in preparations from certain fungi such as Polyporus versicolor $(1,29)$ and Lactarius spp. $(11,12)$, in which it is thought that polyphenoloxidases (laccases), rather than peroxidase, are responsible for IAA oxidation. The present paper concerns the IAAoxidizing enzyme of cultures of the fungus Omphalia flavida (Mycena citricolor), which is shown to depend upon peroxidase activity.

Existing views about the mechanism of peroxidase-catalyzed oxidations of IAA are rather widely divergent. Galston, Bonner,

1 Part of this work was carried out while the author was a member of the Society of Fellows of Harvard University. The work received support from National Science Foundation Grant NSFG182 to Professor K. V. Thimann. and Baker $(3,4)$ concluded that IAA oxidation in pea homogenates results from the combined action of a peroxidase and a flavine enzyme, the latter enzyme reacting with oxygen to produce hydrogen peroxide, which is utilized by the former enzyme. This general type of reaction sequence can be formulated

$$
\begin{gathered}
\text { IAA }+\mathrm{H}_{2} \mathrm{O}_{2} \stackrel{\text { peroxidase }}{\longrightarrow} \mathrm{P}_{1}+2 \mathrm{H}_{2} \mathrm{O} \\
\mathrm{P}_{1}+\mathrm{O}_{2} \stackrel{\text { flavine }}{\longrightarrow} \mathrm{P}_{2}+\mathrm{H}_{2} \mathrm{O}_{2}
\end{gathered}
$$

The involvement of a flavine enzyme was questioned by Kenten (9), who observed rapid IAA oxidation by purified horse-radish peroxidase preparations, and could find no evidence that a flavine was present. Stutz $(24,25)$ suggested that the purified IAAoxidizing enzyme from Lupinus albus possesses separate peroxidase and dehydrogenase-like centers, the action of which is coupled through peroxides.

A major line of evidence for the occurrence of reaction (1) has been the inhibitory effect of polyphenols upon IAA oxidation, since 
these are typical peroxidase substrates and would be expected to compete with IAA for $\mathrm{H}_{2} \mathrm{O}_{2}$. Only Platt (14a) has reported direct evidence for the occurrence of reaction (1). Waygood, Oaks, and Maclachlan $(14,31)$ concluded that in IAA oxidation a peroxide other than $\mathrm{H}_{2} \mathrm{O}_{2}$ serves as $\mathrm{H}$ acceptor for peroxidase, and that polyphenols inhibit by reacting with other components of the system than peroxidase. They formulated the reaction as an oxidation of IAA by $\mathrm{Mn}^{3+}$ generated indirectly by peroxidase, and obtained evidence that oxygen uptake results from a reaction between $\mathrm{O}_{2}$ and radicals formed by the initial oxidation of IAA. This would mean that neither IAA nor $\mathrm{O}_{2}$ reacts with an enzyme during IAA oxidation.

Yamazaki and Souzu (32) recently obtained evidence for the occurrence of the reaction

$$
\mathrm{IAA}+1 / 2 \mathrm{H}_{2} \mathrm{O}_{2} \stackrel{\text { peroxidase }}{\longrightarrow} \mathrm{P} \bullet+\mathrm{H}_{2} \mathrm{O}
$$

in which strongly reducing radicals $(\mathrm{P} \bullet$ ) are formed. He considered that $\mathrm{H}_{2} \mathrm{O}_{2}$ is probably regenerated in a reaction between $\mathrm{P}$. and $\mathrm{O}_{2}$, which would occur spontaneously.

The present experiments were conducted to investigate the relationship between peroxidase activity and IAA oxidation in Omphalia enzyme preparations. Attention was given to the question of how polyphenols inhibit, and indications were obtained that IAA reacts directly with peroxidase, although not in a simple peroxidation like Eq. (1). Inhibition by carbon monoxide was also studied.

\section{MATERIALS}

Enzymic reactions were conducted in sodium citrate buffer, $\mathrm{pH} 3.7$, unless indicated otherwise. Buffers were prepared by adjusting a solution of the acid to the desired $\mathrm{pH}$ with $\mathrm{NaOH}$. IAA (Hoffmann-LaRoche Ltd.) was dissolved in water by adding an equivalent amount of $\mathrm{NaOH}$ and warming gently. $\mathrm{H}_{2} \mathrm{O}_{2}$ solutions were prepared by dilution of Merck "Superoxol" $\mathrm{H}_{2} \mathrm{O}_{2}$ solution, and standardized against permanganate. Pyrex-redistilled water, and glassware rinsed in such water, was used for all solutions. Gas mixtures were prepared from commercial tank gases (purified grades), first passed through ascarite.

\section{METHODS}

\section{Enzyme Preparation}

The IAA-destroying enzyme of Omphalia flavida was obtained from cultures of the fungus on synthetic liquid medium, as previously described (20). The enzyme was purified from the culture medium by the following procedure, which was carried out at $3^{\circ} \mathrm{C}$.

1. Exhaustive dialysis against glass-redistilled water, replaced five times over a period of 1 week.

2. Precipitation with saturated ammonium sulfate, followed by exhaustive dialysis of the redissolved orange precipitate against glass-redistilled water.

3. Adsorption on $\mathrm{Ca}_{3}\left(\mathrm{PO}_{4}\right)_{2}$ gel, prepared according to the method of Singer and Kearney (23), and elution with $1.5 \times 10^{-3} \mathrm{M} \mathrm{Na}_{2} \mathrm{HPO}_{4}$, followed by exhaustive dialysis against glass-redistilled water. The product was a clear watery solution with a weak absorption maximum at $410 \mathrm{~m} \mu$.

\section{Assay of IAA-Oxidizing Activity}

In measurement of enzyme activity, $\mathrm{H}_{2} \mathrm{O}_{2}$ was added in amount greater than $2 \times 10^{-6} M$. The purpose of this is to avoid induction effects and bring about a steady initial reaction rate capable of being accurately determined. The course of the reaction in the absence of added $\mathrm{H}_{2} \mathrm{O}_{2}$, and the effect of $\mathrm{H}_{2} \mathrm{O}_{2}$ on the reaction rate are considered in the following paper of this series (19). The amount of $\mathrm{H}_{2} \mathrm{O}_{2}$ added in assay was sufficient to make the rate independent of $\mathrm{H}_{2} \mathrm{O}_{2}$ concentration, but was much less than the amount of IAA oxidized during the experiment.

In the standard assay of IAA-destroying activity, the reaction was conducted for $6 \mathrm{~min}$. at $25^{\circ} \mathrm{C}$. in $1 \mathrm{ml}$. of solution containing enzyme, 0.09 $\mu$ mole IAA, $0.005 \mu$ mole $\mathrm{H}_{2} \mathrm{O}_{2}$, and 0.05 mmole sodium citrate ( $\mathrm{pH} 3.7$ ). The rcaction was stopped by adding $2 \mathrm{ml}$. of Salkowski reagent (6), and the remaining IAA was determined by measuring optical density at $530 \mathrm{~m} \mu$ after $45 \mathrm{~min}$. Activity was determined using an amount of enzyme which destroyed about one-third of the added IAA during the test.

IAA oxidation was measured spectrophotometrically according to Ref. (18).

\section{Assay of Peroxidase Activity}

Measurement of pyrogallol peroxidation was performed spectrophotometrically by following the increase in optical density at $380 \mathrm{~m} \mu$.

Assay of peroxidase activity was carried out at $25^{\circ} \mathrm{C}$. in $3 \mathrm{ml}$. of solution containing enzyme, 15 $\mu$ moles sodium citrate $(\mathrm{pH} 3.7), 0.6 \mu$ mole pyro- 
gallol, and $0.9 \mu$ mole $\mathrm{H}_{2} \mathrm{O}_{2}$. After $6 \mathrm{~min}$., $0.1 \mathrm{ml}$. of $3.75 \% \mathrm{H}_{2} \mathrm{SO}_{4}$ was added to stop the reaction, and the optical density at $380 \mathrm{~m} \mu$, which was stable, was subsequently determined.

\section{RESULTS}

\section{Peroxidase Activity of tile OMPhalia ENzYME}

In the absence of added $\mathrm{H}_{2} \mathrm{O}_{2}$, no oxidation of polyphenols such as pyrogallol, catechol, or guaiacol took place in the presence of either crude or purified preparations of the Omphalia enzyme. They evidently contain no polyphenolase activity. If $\mathrm{H}_{2} \mathrm{O}_{2}$ were added, rapid formation of colored oxidation products occurred, in an amount dependent upon the amount of $\mathrm{H}_{2} \mathrm{O}_{2}$ added. The rate was proportional to enzyme concentration.

Table I presents final changes in optical density, from which the value 1.5 for the $\mathrm{H}_{2} \mathrm{O}_{2}$ to pyrogallol stoichiometry can be calculated. Although this figure corresponds to the formation of purpurogallin, this substance did not appear to be the principal product, because the absorption spectrum formed in the solution consisted of generally rising absorption into the ultraviolet, with a shoulder at about $260 \mathrm{~m} \mu$ and a broad subsidiary maximum at $380 \mathrm{~m} \mu$, a spectrum unlike that of pure purpurogallin (7).

The effect of $\mathrm{pH}$ on the rate of pyrogallol peroxidation is shown in curve 1 of Fig. 1. The Omphalia peroxidase is unusual (although apparently not unique, cf. [16]) in exhibiting optimum activity at $\mathrm{pH}$ 3.5-3.7. Curve 2 of Fig. 1 shows an experiment in which the $\mathrm{pH}$ dependence of IAA oxidation by this enzyme preparation was determincd; it is seen that the effect of $\mathrm{pH}$ on IAA oxidation is very similar to that on pyrogallol peroxidation.

Although the $\mathrm{pH}$ optimum of 3.5-3.7 for the Omphalia enzyme seems very distinctive, it appeared possible that it might be the result of the conditions employed. A similar optimum was obtained previously for IAA oxidation by the Omphalia enzyme in the absence of added $\mathrm{H}_{2} \mathrm{O}_{2}$ (20). IAA oxidation by pea homogenales has been reported by Reinert et al. (21) to show an optimum at
TABLE I

Stoichiometry of Pyrogallol Peroxidation

\begin{tabular}{|c|c|c|c|c|}
\hline Cuvette & 1 & 2 & 3 & 4 \\
\hline Pyrogallol, mmoles & 1.0 & 1.0 & 1.0 & 1.0 \\
\hline $\mathrm{H}_{2} \mathrm{O}_{2}$, , moles & 3.0 & 1.0 & 0.5 & 0.25 \\
\hline Final $E_{380}$ & 0.490 & 0.330 & 0.167 & 0.079 \\
\hline Pyrogallol oxidized ${ }^{a}$ & 1.0 & 0.67 & 0.34 & 0.16 \\
\hline Stoichiometry & - & 1.5 & 1.5 & 1.6 \\
\hline
\end{tabular}

a Calculated on the basis of complete oxidation in cuvette 1 , which contained excess $\mathrm{H}_{2} \mathrm{O}_{2}$.

about $\mathrm{pH} 4$ only if high concentrations of $\mathrm{Mn}^{++}$are added; however, no $\mathrm{Mn}$ was added in the $\mathrm{pH}$ experiments with the Omphalia enzyme mentioned above. Maclachlan and Waygood (13) stated that citrate inhibits IAA oxidation above $\mathrm{pH} 4$ but not at more acidic $\mathrm{pH}$, so it seemed possible that the $\mathrm{pH}$ optimum might depend upon the buffer used. The effect of $\mathrm{pH}$ on IAA oxidation was therefore examined using as buffers propionate and phosphate, which would not be expected to show the chelating properties to which

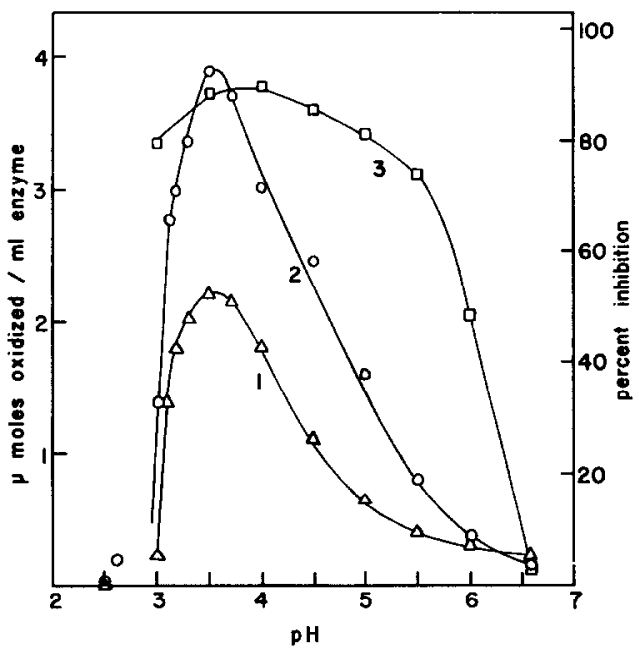

FIG. 1. Curve 1, effect of $\mathrm{pH}$ on peroxidation of pyrogallol by Omphalia enzyme (left ordinate); $2 \times 10^{-4} M$ pyrogallol and $3 \times 10^{-4} \mathrm{M} \mathrm{H}_{2} \mathrm{O}_{2}$. Curve 2, effect of $\mathrm{pH}$ on IAA oxidation; $9 \times 10^{-5}$ $M$ IAA and $4 \times 10^{-6} M \mathrm{H}_{2} \mathrm{O}_{2}$. Curve 3, effect of $\mathrm{pH}$ on inhibition of pyrogallol peroxidation by $5 \times$ $10^{-5} M$ IAA (right ordinate); conditions as in curve 2. All experiments done in $5 \times 10^{-3} M \mathrm{Na}$ citrate buffers. 
inhibition by citrate is ascribed. Each was employed over the $\mathrm{pH}$ range in which it constitutes an effective buffer. The results, given in Fig. 2, show that the IAA oxidation rate responded to $\mathrm{pH}$ in a qualitatively similar manner regardless of buffer used; the optimum lay on the acid side beyond the buffering limit of either buffer. Addition of promoting concentrations of 2,4-dichlorophenol also did not qualitatively alter the $\mathrm{pH}$ response, but since dichlorophenol promotion appeared at lower concentration at the higher $\mathrm{pH}$ values (19), some alteration in the proportions of the curve resulted.

To test whether different enzymes might be responsible for pyrogallol peroxidation and IAA oxidation, an Omphalia enzyme preparation was subjected to thermal inactivation at $70^{\circ} \mathrm{C}$, samples being withdrawn at intervals and subsequently assayed for IAA-oxidizing and pyrogallol-peroxidizing activities. The results are given in Table II; they show a close proportionality between the two activities even after activity had been reduced to about $3 \%$ of that initially present.

In Table III the change in IAA-oxidizing and pyrogallol-peroxidizing activity is compared in the course of purification by the procedure given above. The ratio of the two activities remained substantially constant,

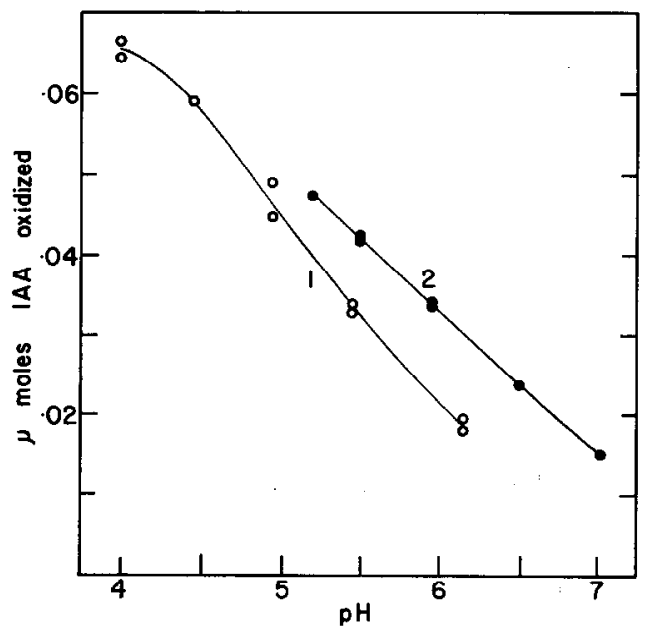

FIg. 2. Effect of $\mathrm{pH}$ on IAA oxidation by $\mathrm{Om}$ phalia enzyme in (curve 1) sodium propionate buffers, and (curve 2) sodium phosphate buffers; concentration of buffers, $0.05 M$.
TABLE II

Thermal Inactivation of Omphalia Enzyme Activities expressed as $\mu$ moles oxidized $/ \mathrm{ml}$. of enzyme solution $/ \mathrm{min}$.

\begin{tabular}{l|c|c|c|c}
\hline \multicolumn{1}{c|}{ Min. at $70 \pm 1^{\circ} \mathrm{C}}$. & 0 & 6 & 15 & 30 \\
\hline $\begin{array}{l}\text { IAA-uxidizing ac- } \\
\text { tivity }\end{array}$ & 0.150 & 0.070 & 0.027 & 0.0049 \\
$\begin{array}{l}\text { Pyrogallol-peroxidiz- } \\
\text { ing activity }\end{array}$ & 0.132 & 0.058 & 0.020 & 0.0037 \\
$\begin{array}{l}\text { Activity ratio } \\
\text { Per cent of initial } \\
\text { activity }\end{array}$ & 100 & 1.1 & 1.3 & 1.3 \\
\hline
\end{tabular}

TABLE III

Fractionation of Omphalia Enzyme

\begin{tabular}{|c|c|c|c|}
\hline Preparation step & 1 & 2 & 3 \\
\hline Vol. of solution. $m l^{a}$ & 245 & 32.1 & 46 \\
\hline Dry weight. $m g . / m l$. & 0.51 & 0.85 & 0.08 \\
\hline$E_{280^{b}}$ & 1.18 & 3.66 & 0.23 \\
\hline IAA oxidation $^{c}$ & 0.127 & 0.667 & 0.270 \\
\hline $\begin{array}{l}\text { Pyrogallol peroxida- } \\
\text { tion }\end{array}$ & 0.147 & 0.736 & 0.287 \\
\hline Activity ratio & 0.86 & 0.90 & 0.94 \\
\hline $\begin{array}{l}\text { Relative IAA activity } \\
\text { (dry wt. basis) }\end{array}$ & 1 & 3.1 & 11 \\
\hline $\begin{array}{l}\text { Per cent recovery of } \\
\text { activity }\end{array}$ & 100 & 69 & 40 \\
\hline
\end{tabular}

a Corrected for removal of samples for assay.

${ }^{\natural}$ Determined on appropriately diluted sample.

c Micromoles oxidized $/ \mathrm{min} . / \mathrm{ml}$. enzyme solution.

even after the loss of activity which occurred in the final step.

From these findings it seems probable that IAA oxidation and pyrogallol peroxidation by the Omphalia enzyme preparations are due to one and the same enzyme. In the inactivation and fractionation experiments, no indication was obtained that the preparations contain any separable factors, or any enzymes other than peroxidase, involved in the IAA-oxidizing reaction.

\section{Inhibition of Pyrogallol Peroxidation by IAA}

Addition of low concentrations of IAA to mixtures of a polyphenol, $\mathrm{H}_{2} \mathrm{O}_{2}$, and the Omphalia enzyme was found to depress the rate of polyphenol oxidation markedly. Fig- 
ure 3 shows progress curves for the reaction, with pyrogallol as substrate, obtained at a series of IAA concentrations. An inhibitory effect is obtained well within what is regarded as the physiological range of IAA concentration. Curve 1 of Fig. 4 shows the inhibition of peroxidase activity as a function of IAA concentration, and compares it with the inhibition by HCN (curve 2). IAA, giving $50 \%$ inhibition at less than $10^{-5} M$, proved to be more than ten times as powerful an inhibitor as HCN under these conditions.

Inhibition was obtained if IAA were added to the reaction mixture when pyrogallol peroxidation was already proceeding. If IAA were added before pyrogallol, and enough time allowed for the IAA to be destroyed by the enzyme before pyrogallol was added, then peroxidation of pyrogallol proceeded at the uninhibited rate. Since inhibition is obtained with amounts of IAA much smaller than the amount of pyrogallol which undergoes oxidation at the inhibited rate, it appears unlikely that interaction of IAA with intermediate products of pyrogallol peroxidation can explain the inhibition.

Inhibition of horse-radish peroxidase by IAA was previously reported by Siegel (22). In the present work, a horse-radish peroxidase preparation was studied under the conditions used in the experiments with the Omphalia enzyme and was found to be considerably less sensitive to IAA, as shown in curve 3 of Fig. 4 . The different behavior of the different enzymes suggests that inhibition by IAA is due to interaction of IAA with the enzyme.

Curve 3 of Fig. 1 shows how the per cent inhibition of peroxidation caused by $5 \times$ $10^{-5} M I \Lambda \Lambda$ varied with $\mathrm{pH}$. A conspicuous decline occurred above $\mathrm{pH}$ 5.5, although even at $\mathrm{pH} 6.630 \%$ inhibition was observed at a tenfold greater IAA concentration.

Table IV shows the effect of some other indole derivatives and acetic acid derivatives on peroxidation of pyrogallol by the Omphalia enzyme. The inhibitory effect is not a general property of either class of compounds. Besides IAA, only indole-3-isobutyric acid and 5 -hydroxyindoleacetic acid, among the compounds tested, gave any de-

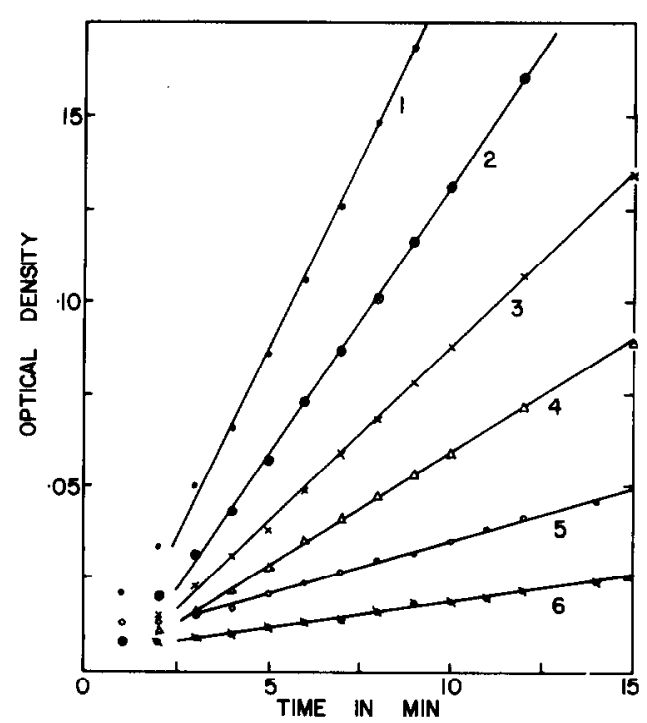

Fig. 3. Effect of IAA on the course of pyrogallol peroxidation followed at $380 \mathrm{~m} \mu$. Pyrogallol and $\mathrm{H}_{2} \mathrm{O}_{2}(0.6 \mu$ mole each $)$ in $3 \mathrm{ml}$. $\mathrm{Na}$ citrate buffer containing enzyme, with IAA concentrations as follows: Curve 1,0 ; curve $2,2.5 \times 10^{-6} \mathrm{M}$; curve $3,7.5 \times 10^{-6} M$; curve $4,1.5 \times 10^{-5} M$; curve 5 , $3.5 \times 10^{-5} \mathrm{M}$; curve $6,7 \times 10^{-5} \mathrm{M}$.

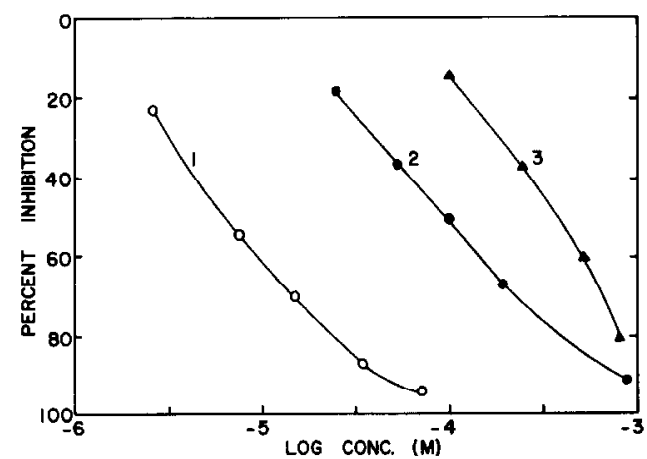

FIG. 4. Inhibition of peroxidases by IAA and HCN. Reaction conditions as in Fig. 3. Curve 1, effect of IAA on Omphalia peroxidase. Curve 2, effect of $\mathrm{HCN}$ (added as $\mathrm{KCN}$ ) on Omphalia peroxidase. Curve 3 , effect of IAA on horse-radish peroxidase.

tectable inhibition. These two compounds are known to be substrates of the oxygenconsuming activity of the enzyme, whereas the remaining compounds are not substrates (20). The inhibition thus appears to be associated with the activity of the enzyme toward oxidation of IAA and related compounds. 
TABLE IV

Inhibition of Pyrogallol Peroxidation

\begin{tabular}{lcc}
\hline & \multicolumn{1}{c}{ Per cent inhibition at } \\
\cline { 2 - 3 } \multicolumn{1}{c}{ Substance } & $\begin{array}{c}5 \times \times \\
10^{-5} M\end{array}$ & $1.8 \times$ \\
& & \\
\hline Indoleacetic acid & 85 & 97 \\
Indoleacetic acid methyl ester & - & 4 \\
Indole-3-propionic acid & - & 3 \\
Indole-3-isobutyric acid & 28 & 54 \\
5-Hydroxyindoleacetic acid & 41 & 65 \\
Indole-3-carboxaldehyde & - & 0 \\
Skatole & - & 0 \\
Imidazole-4-acetic acid & - & 0 \\
Benzofurane-3-acetic acid & - & 0 \\
2,4-Dichlorophenoxyacetic acid & - & 2 \\
Naphthalene-1-acetic acid & - & 0 \\
\hline
\end{tabular}

The inhibition of peroxidation caused by $8 \times 10^{-6} M$ IAA was determined at pyrogallol concentrations varying from $2 \times 10^{-4}$ to $1.25 \times 10^{-3} M$, as shown in Fig. 5. With increasing pyrogallol concentration, the uninhibited reaction rate increased more than in proportion to the IAA-inhibited rate, so that per cent inhibition actually increased, i.e., increase in pyrogallol concentration did not reverse the inhibition. The results, therefore, are not an instance of kinetically "competitive" inhibition.

\section{INHIBITION OF IAA OXIDATION By Polyphenols}

Oxidation of IAA by the Omphalia enzyme is, like other IAA oxidations, strongly inhibited by $o$ - and $p$-diphenols and polyphenols, such as catechol, hydroquinone, and pyrogallol, at concentrations of about $10^{-5} M$. When followed manometrically this inhibition appeared as a depression of the rate of $\mathrm{O}_{2}$ uptake, without much increase in the short induction period which always precedes attainment of a steady rate of oxygen consumption. This differs from the inhibitions reported for horse-radish peroxidase (9), Lupinus enzyme (24), and wheat-leaf enzyme preparation (31), where polyphenols brought on an extended lag in the beginning of $\mathrm{O}_{2}$ uptake. Whether this difference is due to the more acidic $\mathrm{pH}$ used for the present enzyme or to other causes is undetermined.

When pyrogallol peroxidation is occurring in the presence of IAA, the inhibition by IAA does not diminish as the reaction progresses, as can be seen in Fig. 3. Consequently, it would appear that IAA is not being destroyed in the course of the experiment. This may be thought surprising, in view of the small amount of IAA which is present, the excess of $\mathrm{H}_{2} \mathrm{O}_{2}$, and the considerable inhibition of pyrogallol peroxidation suggestive of an interaction of IAA with the enzyme. Since colorimetric determination of IAA in the presence of the amounts of polyphenol and $\mathrm{H}_{2} \mathrm{O}_{2}$ used in such experiments is very unreliable (15), two physical methods were employed to ascertain how much IAA destruction was actually occurring in the presence of pyrogallol and excess $\mathrm{H}_{2} \mathrm{O}_{2}$.

To assay IAA at low concentrations, in the range giving partial inhibition of pyrogallol peroxidation, advantage was taken of the fact that the products of IAA destruction are neutral. IAA labeled with $\mathrm{C}^{14}$ in the 2carbon of the indole ring was used, and the amount of acidic ether-soluble label (residual IAA) was determined. With $5 \times 10^{-6}$ $M$ IAA, which gave $51 \%$ inhibition of pyrogallol peroxidation, IAA destruction appeared to be at least $95 \%$ inhibited over that in the absence of pyrogallol.

At IAA concentrations above about $4 \times$ $10^{-5} M$, its oxidation may be followed spectrophotometrically at $261 \mathrm{~m} \mu$ (18). Peroxidation of pyrogallol causes increases in optical density at $261 \mathrm{~m} \mu$ and also at $380 \mathrm{~m} \mu$, a

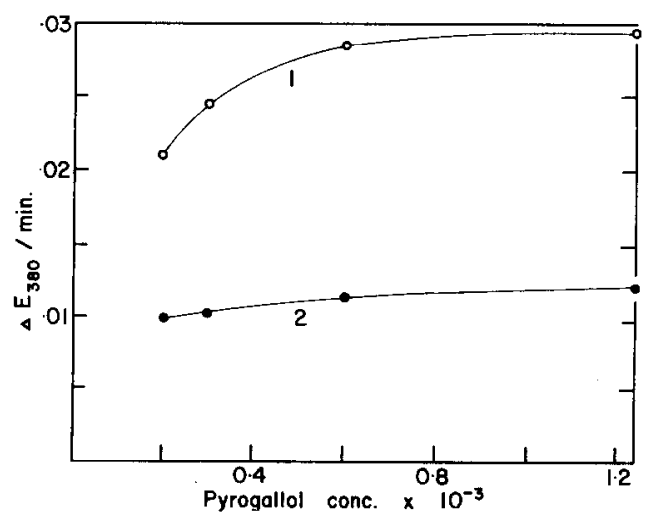

Fig. 5. Effect of pyrogallol concentration on inhibition of peroxidation by IAA. Curve 1 , control rate; curve 2 , rate in presence of $8 \times 10^{-6} M$ IAA. Reaction conditions as in Fig. 3. 
TABLE $\mathrm{V}$

Interaction between IAA and Pyrogallol Oxidations

Rates of oxidation measured spectrophotometrically for IAA or pyrogallol separately in the pres. ence of the Omphalia enzyme and indicated concn. of $\mathrm{H}_{2} \mathrm{O}_{2}$, and determined for samples containing both IAA and pyrogallol by the two-component method described in the text.

\begin{tabular}{|c|c|c|c|c|c|c|c|c|c|}
\hline \multirow{2}{*}{ Expt. No. } & \multicolumn{3}{|c|}{ Substrates, $M \times 10^{-5}$} & \multicolumn{2}{|c|}{ IAA oxidation } & \multicolumn{2}{|c|}{ Pyrogallol peroxidation } & \multicolumn{2}{|c|}{ Per cent inhibition } \\
\hline & IAA & Pyrogallow & $\mathrm{H}_{2} \mathrm{O}_{2}$ & alone & $\begin{array}{c}\text { w/pyro- } \\
\text { gailol }\end{array}$ & w/IAA & alone & $\begin{array}{c}\text { IAA } \\
\text { oxidation }\end{array}$ & $\begin{array}{c}\text { Pyrogallol } \\
\text { peroxida } \\
\text { tion }\end{array}$ \\
\hline & & & & \multicolumn{2}{|c|}{ mumoles/min. } & \multicolumn{2}{|c|}{ mumoles/min. } & & \\
\hline 1 & 6.0 & 0.65 & 1.6 & 25 & 4.0 & 2.4 & $a$ & 84 & $a$ \\
\hline 2 & 6.4 & 3.3 & 6.6 & 9.5 & 0.4 & 2.8 & 21 & 95 & 85 \\
\hline 3 & 5.9 & 6.6 & 3.3 & 16.5 & 1.1 & 4.3 & 32 & 94 & 87 \\
\hline 4 & 6.5 & 6.6 & 13.4 & 10.3 & 0.2 & 3.5 & 43 & 98 & 91 \\
\hline
\end{tabular}

a Not determined.

wavelength at which IAA oxidation causes negligible changes at the concentration used. If the relationship between optical changes at 261 and $380 \mathrm{~m} \mu$ due to pyrogallol peroxidation is first determined, then a two-component analysis of mixtures of IAA and pyrogallol, both undergoing oxidation, may be made by following extinction simultaneously at 261 and $380 \mathrm{~m} \mu$. The results of several experiments with this method are given in Table $V$. In all cases the rates of both IAA and pyrogallol oxidation were strongly inhibited when the two substrates were present together. The figures for pyrogallol peroxidation are given in terms of the equivalent amount of $\mathrm{H}_{2} \mathrm{O}_{2}$ consumed. The amount of $\mathrm{H}_{2} \mathrm{O}_{2}$ used in peroxidation of pyrogallol, in the presence of IAA, was considerably less than the amount by which IAA oxidation was being inhibited. The inhibition of IAA oxidation cannot, therefore, be explained by saying that $\mathrm{H}_{2} \mathrm{O}_{2}$ is diverted from Eq. (1) to peroxidation of the phenol, or attributed to a competition between phenol and IAA for $\mathrm{H}_{2} \mathrm{O}_{2}$. The results suggest that in the presence of both substrates an inactive form of the enzyme, incapable of oxidizing either of them, accumulates.

\section{EFFect of Oxygen}

Substrate amounts of $\mathrm{H}_{2} \mathrm{O}_{2}$ were added to IAA and the enzyme, in the presence and absence of oxygen, and IAA destruction followed spectrophotometrically (thus avoiding the interfering effect of substrate quan- tities of $\mathrm{H}_{2} \mathrm{O}_{2}$ on the colorimetric determination). The measured rate of IAA destruction in the absence of oxygen was always less than $10 \%$ of that in air, and the amount of IAA destroyed never reached more than a small fraction of the amount of $\mathrm{H}_{2} \mathrm{O}_{2}$ added. Table VI gives results of one such experiment. This contrasts sharply with pyrogallol peroxidation, which, as can be seen in curves 1 and 2 of Fig. 6, is quite unaffected by the presence or absence of oxygen. It would appear that a peroxidative reaction like reaction (1) should also be insensitive to oxygen.

Although peroxidation of pyrogallol was indifferent to oxygen, the inhibitory effect of IAA on peroxidation of the phenol was markedly increased in the absence of oxy-

\section{TABLE VI}

EFFECT OF $\mathrm{O}_{2}$ ON IAA OxIDATION

Evacuated Thunberg tubes contained 0.15 $\mu$ mole IAA, and $\mathrm{H}_{2} \mathrm{O}_{2}$, in $3.5 \mathrm{ml}$. buffer, with enzyme in side arm; air was admitted to appropriate tubes. Figures show difference between extinctions at 261 and $272 \mathrm{~m} \mu$, determined against a blank containing buffer and IAA, $30 \mathrm{~min}$. after contents of tubes and side arms were mixed. Each figure is the average of two determinations; zero value 0.006 .

\begin{tabular}{lcc}
\hline \multirow{2}{*}{ Micromoles $\mathrm{H}_{2} \mathrm{O}_{2}$} & \multicolumn{2}{c}{$E_{201}-E_{2 / 2}$} \\
\cline { 2 - 3 } & Air & Vacuum \\
\hline 0.01 & 0.098 & 0.006 \\
0.10 & 0.077 & 0.004 \\
\hline
\end{tabular}




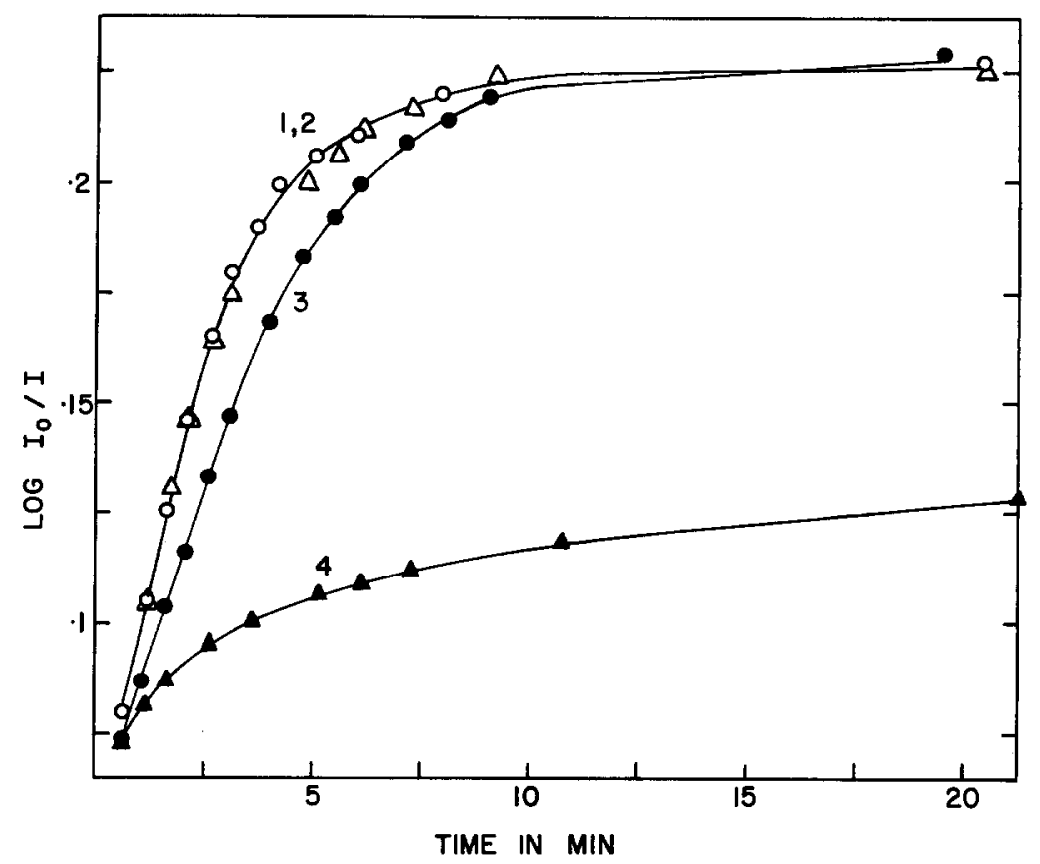

FIG. 6. Effect of oxygen on pyrogallol peroxidation in absence and presence of $5 \times 10^{-6} M$ IAA Curve 1 (open circles), control in air; curve 2 (open triangles), control in vacuo; curve 3 , with IAA, in air; curve 4, with IAA, in vacuo. Thunberg tubes contained $6.6 \times 10^{-5} M$ pyrogallol and $10^{-4} M \mathrm{H}_{2} \mathrm{O}_{2}$; enzyme solution was held in side arm while tubes were evacuated, air was readmitted to tubes 1 and 3 , and all side arms were then tipped. Absorption was followed at $380 \mathrm{~m} \mu$ versus air.

gen. Figure 6 shows an experiment in which the effect of $5 \times 10^{-6} M$ IAA on pyrogallol peroxidation was tested in the presence and absence of air. Inhibition in air was $28 \%$; in the absence of air it was $60 \%$ initially and increased further as the reaction progressed. It seems unlikely that the stronger inhibition observed anaerobically could be due simply to conservation of IAA through prevention of its destruction, since, as was brought out above, even in air at most only a small fraction of the IAA added undergoes destruction in this type of experiment. Oxygen appears rather to protect the enzyme partially against inhibition by IAA.

If air were introduced into a mixture containing enzyme, $\mathrm{H}_{2} \mathrm{O}_{2}$, and IAA, which had been incubated anaerobically for several minutes, a rapid reaction would ensue only if more enzyme were added, suggesting that the original enzyme had been inactivated in some way not directly reversible by oxygen. This introduces a difficulty into the attempt to demonstrate reaction (1), because it is not known whether the absence of reaction is due primarily to lack of oxygen or to inactivation of enzyme. What can be pointed out is that peroxidation of pyrogallol shows no such effect of oxygen, indicating an involvement of oxygen in IAA oxidation more direct than is implied in separate reactions (1) and (2). Likewise, admission of air to an evacuated system containing enzyme, $\mathrm{H}_{2} \mathrm{O}_{2}, \mathrm{IAA}$, and pyrogallol would only partially reverse the inhibition of pyrogallol peroxidation. ${ }^{2}$

\section{INHIBITION OF IAA OXIDATION BY CO}

A possible interpretation of the interaction between IAA oxidation and pyrogallol peroxidation is that in the presence of IAA, a form of the enzyme appears which is inactive in peroxidation but may possibly be involved in a reaction with oxygen. On this

2 Yamazaki and Souzu (32) recently reported inhibition of turnip peroxidase when IAA and $\mathrm{H}_{2} \mathrm{O}_{2}$ were incubated with it anaerobically. They attributed it to reaction of $\mathrm{P} \cdot[\mathrm{Eq} .(3)]$ with the enzyme. 


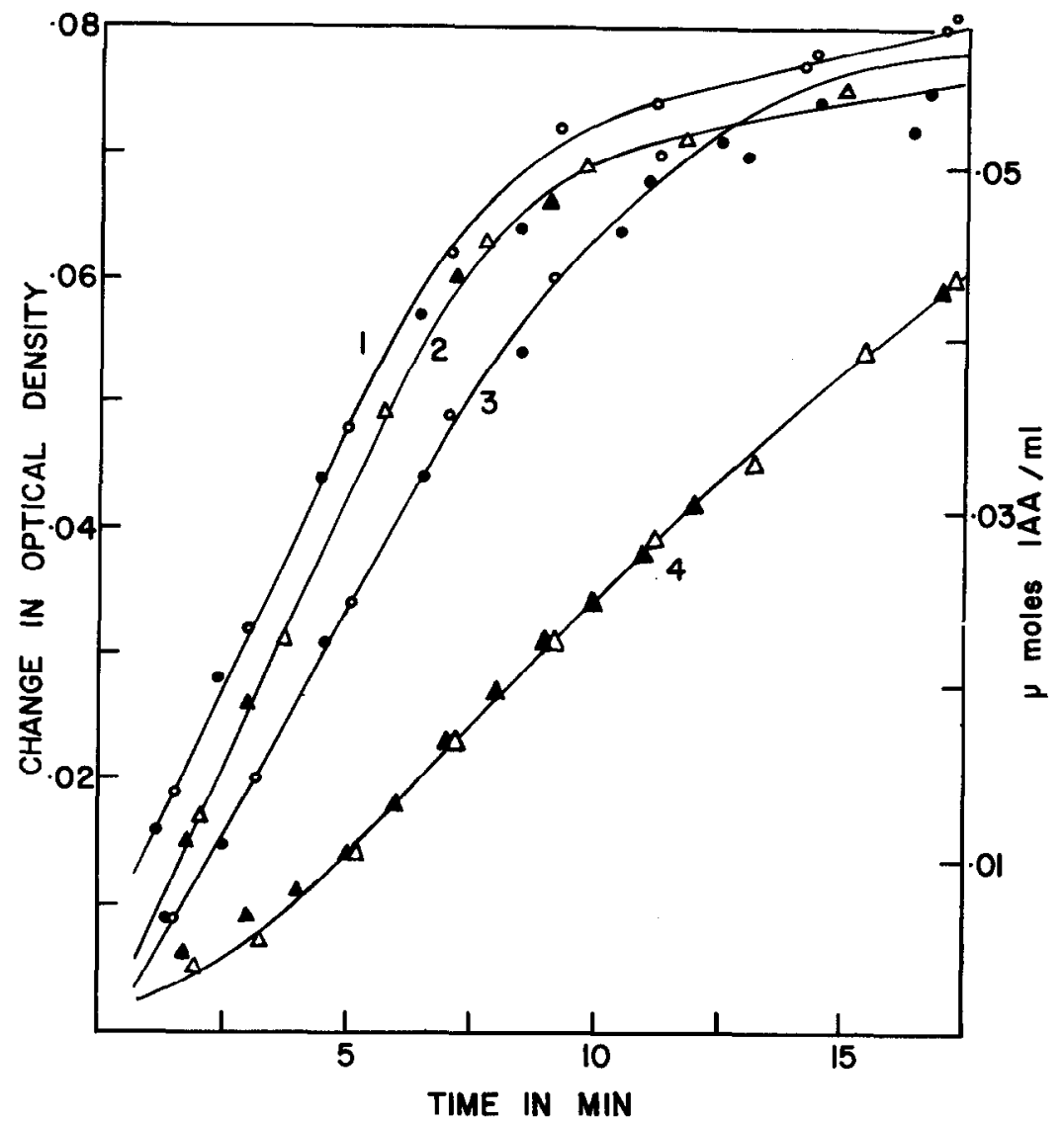

FIG. 7. Effect of carbon monoxide and light on IAA oxidation followed at $261 \mathrm{~m} \mu$. Curve 1, 5\% $\mathrm{O}_{2} /$ $95 \% \mathrm{~N}_{2}$ in light; curve 2 , same in dark; curve $3,5 \% \mathrm{O}_{2} / 95 \% \mathrm{CO}$, in light; curve 4, same in dark. Cuvettes contained $0.18 \mu$ mole IAA and $0.03 \mu$ mole $\mathrm{H}_{2} \mathrm{O}_{2}$ in $2.9 \mathrm{ml}$., and were gassed for 5 min. Enzyme solution was evacuated separately, and $0.15 \mathrm{ml}$. was introduced into cuvette, under a stream of the gas mixture, at zero time. Illumination from two 15-w. daylight fluorescent lamps at a distance of $15 \mathrm{~cm}$. Solid and open symbols show duplicate experiments.

account it was especially interesting to find that IAA oxidation by the Omphalia enzyme showed definite light-reversible inhibition by carbon monoxide. Curve 4 of Fig. 7 shows the inhibitory effect of $95 \%$ $\mathrm{CO} / 5 \% \mathrm{O}_{2}$ in the dark, against a control of $95 \% \mathrm{~N}_{2} / 5 \% \mathrm{O}_{2}$ (curve 2). Curve 1 is the same control run in the light, indicating no effect of light on the reaction in the absence of $\mathrm{CO}$. With $\mathrm{CO}$, however, curve 3 was obtained in the light and shows almost complete reversal of inhibition. Inhibition by CO was also observed in manometric experiments, in which $\mathrm{H}_{2} \mathrm{O}_{2}$ was not added. Using gas mixtures similar to those in Fig. 7 , the same degree of inhibition (about $50 \%$ ) was observed, and reversal by light was complete.

Figure 8 shows how the rate of IAA oxidation depended upon $\mathrm{CO}$ pressure at constant $\mathrm{O}_{2}$ tension. Inhibition reached $50 \%$ at about $0.5 \mathrm{~atm}$. CO, and could not be increased much by further increase in CO pressure, except at the beginning of the reaction. At higher $\mathrm{CO}$ pressures the initially slow rate rose during several minutes to a steady value shown by solid circles in Fig. 8. The open circles in Fig. 8 show an estimate of the initial rates. Below 0.5 atm. CO, the rates were steady from the first observation.

Increasing the $\mathrm{O}_{2}$ pressure decreased the per cent inhibition due to $\mathrm{CO}$ and tended 


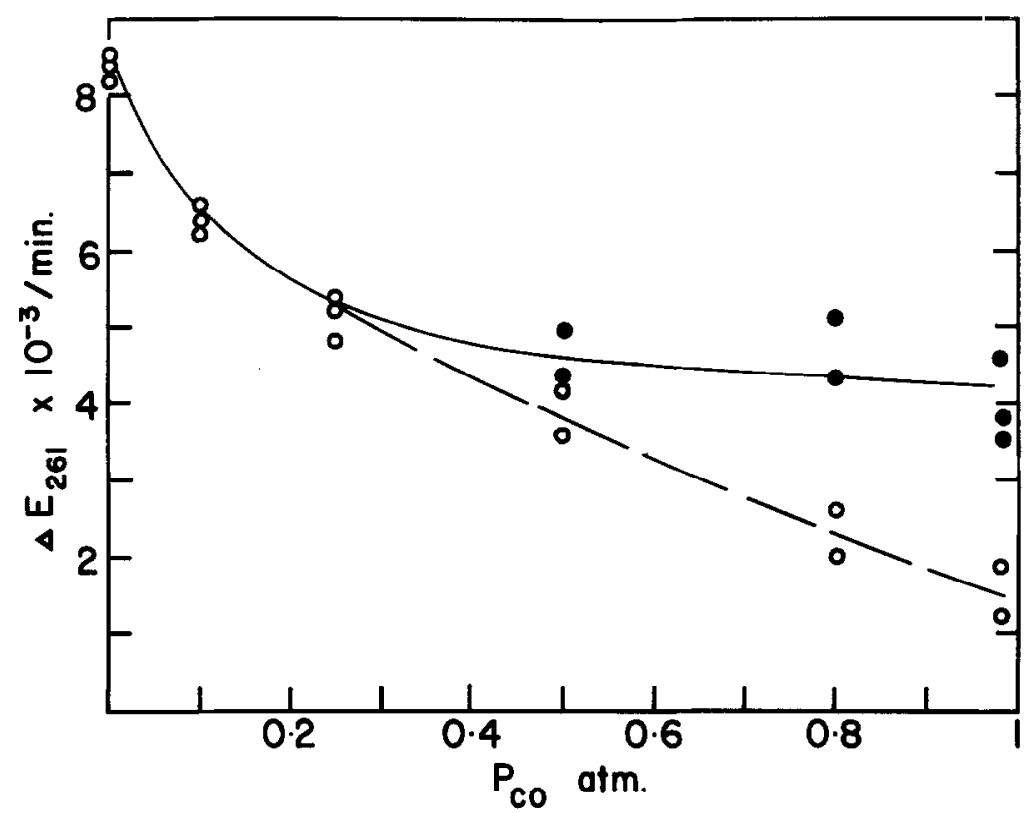

FIG. 8. Effect of CO pressure on oxidation of IAA in the dark. Conditions similar to those of Fig. 7. All gas mixtures contained $2 \% \mathrm{O}_{2}$, and were made to $100 \%$ with $\mathrm{N}_{2}$. Open symbols show initial rates of reaction; solid symbols show the steady rate eventually reached, in cases where it differed from the initial rate.

TABLE VII

EFFECT of $\mathrm{O}_{2}$ ON CO InHibition of IAA OxIDATION

\begin{tabular}{|c|c|c|c|}
\hline \multirow{3}{*}{$\mathrm{CO}$, atm. } & \multicolumn{3}{|c|}{ Oxygen, atm. } \\
\hline & 0.02 & 0.20 & 0.90 \\
\hline & \multicolumn{3}{|c|}{ Per cent inhibition ${ }^{a}$} \\
\hline 0.10 & 29.5 & - & 19 \\
\hline 0.80 & 55 & 30 & 一 \\
\hline
\end{tabular}

a Per cent inhibition over $\mathrm{O}_{2} / \mathrm{N}_{2}$ mixture of same $P_{\mathrm{O}_{2}}$; each determination in duplicate. Reaction conditions similar to those in Fig. 7.

to eliminate the induction effect caused by CO. The results of some experiments at different oxygen concentrations are given in Table VII. Increases in $\mathrm{O}_{2}$ concentration did not reverse the inhibition to the extent which might have been expected if $\mathrm{O}_{2}$ and $\mathrm{CO}$ were competing in the same reaction, and rather suggest that the effect of $\mathrm{O}_{2}$ on the $\mathrm{CO}$ inhibition may be indirect.

\section{DISCUSSION}

The light-reversible inhibitory effect of CO suggests that ferrous peroxidase may be formed during the oxidation of IAA, since ferrous peroxidase is known to give a lightdissociable $\mathrm{CO}$ complex (8). Formation of ferrous hemoprotein has been proposed, on the basis of inhibition by $\mathrm{CO}$, for several analogous oxygen-consuming reactions: the oxidation of dihydroxyfumaric acid by horseradish peroxidase (26), the oxidation of tryptophan by tryptophan peroxidase (10), and the oxidation of azide by catalase (28). Tang and Bonner (27) previously reported inhibition of IAA oxidation by $\mathrm{CO}$, but, as pointed out by Wagenknecht and Burris (30), their interpretation is rendered doubtful because of the control used. It is felt that the present experiments demonstrate genuine light-reversible inhibition by $\mathrm{CO}$.

Could ferrous peroxidase be the inactive form of the enzyme which appears in the presence of IAA, and accounts for the inhibition of peroxidation by IAA? Reconversion of ferrous to ferric form or a peroxide complex thereof might then be the step involving oxygen indicated by the effect of oxygen on IAA oxidation, on $\mathrm{CO}$ inhibition, and on IAA inhibition of peroxidation. The excessively inhibitory effect of polyphenols on IAA oxidation suggested (17) that a free- 
radical process could be involved, since polyphenols act as antioxidants by combining with free radicals (2). If a free-radical mechanism were the basis for reaction of oxygen with the system, as is considered to be the case in many organic autoxidations, it would be apparent why polyphenols inhibit reconversion of the inactive (ferrous) to the active (ferric) form, and inhibition of both peroxidation and IAA oxidation results.

Although reaction sequences can be written for IAA oxidation based on a free-radical mechanism involving ferrous peroxidase, their relation to existing evidence would be largely speculative. Moreover, it is not established that inhibition of peroxidation by IAA and inhibition of IAA oxidation by $\mathrm{CO}$ involve the same form of the enzyme. The effect of $\mathrm{CO}$ on the inhibition of pyrogallol peroxidation by IAA was tested, in the expectation that if the same form of the enzyme were involved, $\mathrm{CO}$ should increase the inhibition. The per cent inhibition by IAA was found not to be markedly affected by $\mathrm{CO}$; in fact, $\mathrm{CO}$ caused a small but definite inhibition of pyrogallol peroxidation alone. Neither is the formation of ferrous peroxidase considered proved by the inhibitory effect of CO. Spectroscopic evidence is needed to show what form of the enzyme does accumulate when $\mathrm{CO}$ is present, or when pyrogallol and IAA are present together; the Omphalia enzyme preparations were not obtained in concentrated enough form for such observations.

Whatever the sequence of reactions which actually occurs during IAA oxidation, it seems probable that an important part of the inhibitory effect of polyphenols on it is due to interference with a mechanism not adequately described by Eq. (1) and (2). This mechanism appears likely to be a freeradical one, as Maclachlan and Waygood (14) and Yamazaki and Souzu (32) have concluded. The nature of the interactions is such as to make difficult a decision as to whether $\mathrm{H}_{2} \mathrm{O}_{2}$ is a reaction intermediate. $\mathrm{H}_{2} \mathrm{O}_{2}$ can certainly enter into the reaction, since it exerts strong effects upon the reaction rate. These are considered in the next paper of this series (19).

\section{ACKNOWLEDGMENTS}

The author wishes to thank Professor K. V. Thimann and Dr. Bruce B. Stowe for their interest in and discussion of this work. He is also indebted to Professor D. Keilin for a discussion of the problem and to Dr. I. Yamazaki for making available a manuscript in advance of publication.

\section{REFERENCES}

1. Fahraeus, G., and Tullander, V., Physiol. Plantarum 9, 494 (1956).

2. Frank, C. E., Chem. Revs. 46, 155 (1950).

3. Galston, A. W., and Baker, R. S., Am. $J$. Botany 38, 190 (1951).

4. Galston, A. W., Bonner, J., and Baker, R. S., Arch. Biochem. Biophys. 42, 456 (1953).

5. Goldacre, P. L., Australian J. Sci. Research, Ser. $B$ 4, 293 (1951).

6. Gordon, S. A., And Weber, R. P., Plant Physiol. 26, 192 (1951).

7. Haworth, R. D., Moore, B. P., and Pauson, P. L., J. Chem. Soc. 1948, 1045.

8. Keilin, D., and Hartree, E. F., Biochem. $J$. 61, $153(1955)$.

9. Kenten, R. H., Biochem. J. 59, 110 (1955).

10. Knox, W. E., Biochim. et Biophys. Acta 14, 117 (1954).

11. Legrand, G., Compt. rend. soc. biol. 151, 921 (1957).

12. Legrand, G., Bull. soc. chim. biol. 39, 1289 (1957).

13. Maclachlan, G. A., and Waygood, E. R., Physiol. Plantarum 9, 321 (1956).

14. Maclachlan, G. A., and Waygood, E. R., Can. J. Biochem. and Physiol. 34, 1233 (1956).

14a. Platt, R. S., Année biol. 30, 349 (1954).

15. Platt, R. S., and Thimann, K. V., Science 123, 105 (1956).

16. Polonovski, M., and Jayle, M. F., Bull. soc. chim. biol. 21, 66 (1939).

17. RAY, P. M., Plant Physiol. 31, xxvii (1956).

18. RAY, P. M., Arch. Biochem. Biophys. 64, 193 (1956).

19. RAY, P. M., Arch. Biochem. Biophys. (in press).

20. Ray, P. M., and Thimann, K. V., Arch. Biochem. Biophys. 64, 175 (1956).

21. Reinert, J., Schraudolf, H., and Reinert, U., Z. Naturforsch. 126, 569 (1957).

22. Siegel, S. M., Physiol. Plantarum 7, 41 (1954).

23. Singer, T. P., and Kearney, E. B., Arch. Biochem. Biophys. 29, 190 (1950).

24. Stutz, R. E., Plant Physiol. 32, 31 (1957).

25. Stutz, R. E., Plant Physial. 33, 207 (1958).

26. Swedin, B., ANd Theorelu, H., Nature 145, $71(1940)$. 
27. Tang, Y. W., and Bonner, J., Arch. Biochem. 30. Wagenknecht, A. C., and Burris, R. H., 13, 11 (1047). Arch. Biochem. 25, 30 (1950).

28. Theoreli, H., and Ehrenberg, A., Arch. 31. Waygood, E. R., Oaks, A., and Maclachlan, Biochem. Biophys. 41, 462 (1952).

G. A., Can. J. Botany 34, 905 (1956).

29. Tonhazy, N. E., and Pelczar, M. J., Science 32. Yamazaki, I., and Souzu, H., Arch. Biochem. 120, 141 (1954). Biophys. 86, 294 (1960) 